\title{
ABC-tiltak på vaklende underlag
}

\author{
Medisinske myter vil nok alltid være en del av den kliniske hverdag. De kan være vanskelige å se og vanske- \\ lige å kvitte seg med. At det er hensiktsmessig å plassere den hypotensive pasient i Trendelenburgs leie, er
} en av disse mytene.

Et sentralt kjennetegn ved moderne medisin er at vitenskapelig kunnskap er grunnlaget for behandlingen vi gir. Men til tross for dette vil medisinske myter kunne lure seg inn i klinisk praksis. Noen eksempler er at metronidazol ikke må kombineres med alkohol, at lokalbedøvelse med adrenalin kan gi nekrose i fingre og tær og at traumatiske hudsår på grunn av infeksjonsfaren må lukkes innen åtte timer (1).

Av anbefalte lavpraktiske tiltak for den hypotensive pasient foreslås sjokkleie (flatt ryggleie med hevede ben i $10-90^{\circ}$ vinkel) og Trendelenburgs posisjon, hvor hele kroppen vinkles $\left(5-60^{\circ}\right)$ med bena høyt (2). En intuitiv oppfattelse av hemodynamikken kan muligens forklare hvorfor praksisen har vært så utbredt, da mobilisering av blod mot sentrale organer bør øke det venøse tilbakeløpet og dermed hjertets minuttvolum.

\section{Usikker utbredelse}

I Trendelenburg survey, publisert for 20 år siden, rapporterte amerikanske intensivsykepleiere omfattende bruk av Trendelenburgs leie mot hypotensjon - til tross for at manglende dokumentasjon og mulige skadevirkninger ble påpekt allerede i 1960årene (3). Selv i dag vil de fleste leger og sykepleiere ha hørt om eller benyttet seg av tiltaket på et eller annet tidspunkt.

Som snart ferdigutdannede leger er vi på forelesninger, på akuttkurs, fra pensum og andre steder blitt anbefalt Trendelenburgs leie som akuttiltak ved hypotensjon. Metoden dukker også opp i diverse kilder som omtaler ABC-håndtering $(4,5)$. I Legevakthåndboken og Norsk legemiddelhåndbok foreslås derimot sjokkleie, mens Norsk Elektronisk Legehåndbok anbefaler flatt ryggleie ved hypovolemisk sjokk og sjokkleie ved anafylaksi.

\section{Sparsom og potensielt negativ effekt} Kunnskapsgrunnlaget for sjokkleie og Trendelenburgs leie ble for fire år siden sammenlignet $i$ en omfattende systematisk litteraturgjennomgang. Konklusjonen var at begge tiltakene gir en øyeblikkelig liten økning i minuttvolum på 6-9\%, men at effekten av Trendelenburgs leie sammenlignet med sjokkleie var kortvarig og midlertidig (2).

Én mulig forklaring på den kortvarige effekten av Trendelenburgs leie er baroreseptorenes relative plassering i forhold til hjertet. Vinklingen av pasienten gir et øt hydrostatisk trykk på baroreseptorene som via refleksbuen kan gi et relativt tap i minuttvolum og hjertefrekvens (6). Det bemerkes dog at man i de fleste studiene ikke fant noe fall i hjertefrekvens. En annen forklaring er at venøst blod akkumuleres i vener, atrium og pulmonal sirkulasjon,

\section{«Tiltaket mangler kunnskapsgrunnlag og er assosiert med komplikasjoner som redusert gassutveks- ling i lungene, aspira- sjon, ugunstige hemo- dynamiske endringer og angst»}

noe som så gir nedsatt venøst tilbakeløp og lavere minuttvolum. Andre studier har heller ikke dokumentert at den initiale økningen i blodtrykk ved Trendelenburgs leie ga bedring i vevsperfusjon eller -oksygenering (7).

En annen mekanisme er at press fra abdominale organer mot diafragma kan gi trykkendringer i thorax og redusert venøst tilbakeløp (2). Det er derfor blitt advart mot bruken av Trendelenburgs leie ved fedme, nedsatt høyre ventrikkel-funksjon, lungesykdom og hodeskader (8). Slike relative kontraindikasjoner svekker den praktiske nytteverdien av tiltaket i en akuttsituasjon.

I flere litteraturstudier advarer man mot eller fraråder bruken av Trendelenburgs leie (9-11). Tiltaket mangler kunnskapsgrunnlag og er assosiert med komplikasjoner som redusert gassutveksling i lungene, aspirasjon, ugunstige hemodynamiske endringer og angst. Også gassemboli ble tidligere behandlet ved å plassere pasienten med hodet lavt, men dette frarådes nå grunnet risikoen for økt intrakranialt trykk og ødem (12)

Det er på tide å innse at Trendelenburgs leie som tiltak ved akutt hypotensjon er utdatert og uten klinisk effekt. Metoden er sjokkleie underlegen - sjokkleie gir ikke bare en mer gunstig hemodynamikk, men man unngår de potensielle negative bivirkningene av Trendelenburgs leie (2).

\section{Fredrik Eika \\ eikafredrik@gmail.com}

Andreas Wahl Blomkvist

Fredrik Eika (f. 1989) er medisinstudent ved Aalborg Universitet og legevikar.

Forfatter har fylt ut ICMJE-skjemaet og oppgir ingen interessekonflikter.

Andreas Wahl Blomkvist (f. 1989) er medisinstudent ved Aalborg Universitet og legevikar. Han var redaktør av AEsculap i 2016.

Forfatter har fylt ut ICMJE-skjemaet og oppgir ingen interessekonflikter.

\section{Litteratur}

Brean A. Myteknuserne. Tidsskr Nor Legeforen 2014; 134: 1633

2. Geerts BF, van den Bergh L, Stijnen T et al. Comprehensive review: is it better to use the Trendelenburg position or passive leg raising for the initial treatment of hypovolemia? J Clin Anesth 2012 24: $668-74$

3. Ostrow CL. Use of the Trendelenburg position by critical care nurses: Trendelenburg survey. Am J Crit Care 1997; 6: 172-6

4. Godtfredsen NS, Kruuse CR, Petersen AM et al. Akutte medicinske tilstande. 11. utg. København: FADL forlag, 2014: 100

5. Lauritsen M. Akutte kirurgiske tilstande. 2. utg København: FADL forlag, 2014: 34

6. Sibbald WJ. Paterson NA, Holliday RL et al. The Trendelenburg position: hemodynamic effects in hypotensive and normotensive patients. Crit Care Med 1979; 7: 218-24

7. Sing RF, O'Hara D, Sawyer MA et al. Trendelenburg position and oxygen transport in hypovolemic adults. Ann Emerg Med 1994; 23: $564-7$.

8. Shammas A, Clark AP. Trendelenburg positioning to treat acute hypotension: helpful or harmful? Clin Nurse Spec 2007; 21: 181-7.

9. Johnson S, Henderson SO. Myth: the Trendelenburg position improves circulation in cases of shock. CJEM 2004; 6: 48-9

10. Bridges N, Jarquin-Valdivia AA. Use of the Trendelenburg position as the resuscitation position: to $T$ or not to T? Am J Crit Care 2005; 14: 364-8.

11. Reuter DA, Felbinger TW, Schmidt $C$ et al. Trendelenburg positioning after cardiac surgery: effects on intrathoracic blood volume index and cardiac performance. Eur J Anaesthesiol 2003; 20: 17-20.

12. Medby C, Brubakk AO, Myrvold HE. latrogen gassemboli. Tidsskr Nor Laegeforen 2001; 121: 2604-6.

Mottatt 18.3. 2017, første revisjon innsendt 22.3. 2017, godkjent 23.3. 2017. Redaktør: Ketil Slagstad.

Publisert først på nett. 